\title{
Standard Oil as a Technological Innovator
}

\section{Citation}

Scherer, F.M. 2011. Standard Oil as a Technological Innovator. HKS Faculty Research Working Paper Series RWP11-008, John F. Kennedy School of Government, Harvard University

\section{Published Version}

http://web.hks.harvard.edu/publications/workingpapers/citation.aspx?Publd=7619

\section{Permanent link}

http://nrs.harvard.edu/urn-3:HUL.InstRepos:4686409

\section{Terms of Use}

This article was downloaded from Harvard University's DASH repository, and is made available under the terms and conditions applicable to Other Posted Material, as set forth at http:// nrs.harvard.edu/urn-3:HUL.InstRepos:dash.current.terms-of-use\#LAA

\section{Share Your Story}

The Harvard community has made this article openly available.

Please share how this access benefits you. Submit a story.

\section{Accessibility}




\title{
Standard Oil as a Technological Innovator Faculty Research Working Paper Series
}

\author{
F.M. Scherer
}

Harvard Kennedy School

\section{January 2011 RWP11-008}

The views expressed in the HKS Faculty Research Working Paper Series are those of the author(s) and do not necessarily reflect those of the John F. Kennedy School of Government or of Harvard University. Faculty Research Working Papers have not undergone formal review and approval. Such papers are included in this series to elicit feedback and to encourage debate on important public policy challenges. Copyright belongs to the author(s). Papers may be downloaded for personal use only. 
STANDARD OIL AS A TECHNOLOGICAL INNOVATOR

\author{
F. M. Scherer \\ Harvard University \\ September 2010 Revision
}

The 1911 Standard 0il case, everyone knows, was all about price discrimination, "predatory" pricing, acquisitions under duress, and the like. But there was also a technological element. Defending against monopolization charges, Standard 0il claimed that it had innovated both technologically and in the scale economies-enhancing investments by which it aggressively expanded its business:

They have been unremitting in their efforts to improve the processes of refining, to diversify the useful byproducts to be obtained from the refining of petroleum and to introduce them into general use, and these efforts have resulted to their great advantage as well as to the general benefit of the industry and the public at large.... They have made great efforts to solve the problem of refining refractory oils and through the success of these efforts they have been able to utilize to their great advantage oils that otherwise were useless except for fuel purposes. ${ }^{1}$

Emphasized among Standard's innovative accomplishments was the Frasch-Burton process (as I shall argue, a misnomer) for deriving satisfactory illuminating oil (kerosene) from the highsulphur oil found in the fields around Lima, Ohio.

In adjudicating the standard oil case, the courts could not ignore Standard's claims of superior entrepreneurship. The Supreme Court observed, for example, that:

[I]n a powerful analysis of the facts, it is insisted [by Standard] that they demonstrate that the origin and development of the vast business which the defendants control was but the result of lawful competitive methods,

* This paper is derived with extensive augmentation and amendment from Scherer (2008).

1 . Brief for Defendants on the Facts, U.S. v. Standard Oil Company (New Jersey) et al., vol. I, pp. 109, 104. 
guided by economic genius of the highest order, sustained by courage, by a keen insight into commercial situations, resulting in the acquisition of great wealth, but at the same time serving to stimulate and increase production, to widely extend the distribution of the products of petroleum at a cost largely below that which would have otherwise prevailed, thus proving to be at one and the same time a benefaction to the general public as well as of enormous advantage to individuals. ${ }^{2}$

Nevertheless, both the Circuit court of first instance and the Supreme Court manifestly failed to address and resolve the contending claims. The supreme court at least admitted the task's difficulty:

[T]o discover and state the truth concerning these contentions both arguments call for the analysis and weighing ... of a jungle of conflicting testimony covering a period of forty years, a duty difficult to rightly perform and, even if satisfactorily accomplished, almost impossible to state with any reasonable regard to brevity. ${ }^{3}$

Instead, asserting from historical and legal reasoning "an obvious truth" that individuals should not be allowed to secure monopolies by wrongful means, the Circuit Court concluded summarily, "Nor can arguments of reduced prices of product, economy in operation, and the like have weight," commencing its remedial order only two paragraphs later. ${ }^{4}$ The Supreme court affirmed, stressing in its precedent-setting rule of reason analysis how Standard's "acts and dealings" revealed the intent to "drive others from the field." 5

One might speculate that the courts in Standard 0il attempted no balancing of the evidence on innovation and cost reduction because the job had been done for them, despite the

2 . Standard Oil Co. v. United States, 221 U.S. 1, 48 (1911).

3 . Ibid.

4 . U.S. v. Standard Oil Co., 178 Fed. 177, 196 (1909).

5 . Supra note 2 at 76. In his dissent, Justice Harlan criticized the majority for articulating its "rule of reason" to adjudicate monopolization cases without any evident basis in Congressional intent. 
evident lack of judicial gratitude, in a massive study the Bureau of Corporations completed two years before the circuit Court delivered its opinion. The Bureau's staff observed inter alia that by far the largest declines in the margin between crude petroleum prices and refined product prices occurred between 1866 and 1872, "before the Standard can be said to have exercised any influence, ${ }^{6}$ that in the first decade of the 20 th Century there was very little difference between the unit costs of Standard refineries and those of its larger rivals (who, it argued, would have been even larger and joined by others but for Standard's restrictive practices), 7 and, on technological innovation : 8

It is a familiar fact that whenever any absolutely new industry springs up, particularly one of a complex character, the costs at the outset are exceedingly high and are rapidly reduced with the first few succeeding years.... It is doubtless true that the standard 0il Company ... was able to secure economies somewhat greater than could have been secured by a number of smaller concerns. It is, however, absurd to contend that no further economies in the industry would have been brought about after 1873 in the absence of the standard or a similar combination.... The reduction of cost, even by small concerns, has been due to the natural development of the industry and to the general progress of science and invention -- not to the enormous aggregation of capital.

\section{A New Analysis of Patenting Trends}

Support for the Bureau's inferences on innovation is provided by an analysis of data the Bureau staff failed to consider (presumably because it was not fashionable in economics to do so at the time, as it is now). From Jacob Schmookler's compilation of U.S. patents issued in various fields, Figure 1 shows the number of petroleum refining patents issued during five-year periods between 1850 and 1929, along with the amount of crude oil produced in the United States during the same periods. ${ }^{9}$ The plot is in logarithmic form, so a straight line implies a constant annual growth rate. The growth of patenting

6 . U.S. Commissioner of Corporations (1907), Part II, "Prices and Profits," p. 625.

7 . Ibid. pp. 650-655.

8 . Ibid., pp. 625-626.

9 . Schmookler (undated), Part II, for Patent Office classes 325 through 332. 
is most rapid before Standard 0il was incorporated and began absorbing competitors in 1870. By 1880, Standard had acquired at least 80 percent of U.S. refining capacity. During its period of dominance, patenting shows no growth and is at lower absolute rates than in 1865-69. After the dissolution of the New Jersey Standard Company in 1912, there is new growth and a substantial increase in the level of patenting.

More detailed scrutiny suggests that the core components of Standard 0il generated only a small share of the 443 refining patents identified in Schmookler's tabulation for the years 1875-1899. A search was conducted in the Patent Office's Annual Index of Patents covering those 25 years for any patent assignment to an entity with the name "Standard 0il..." along with 50 subsidiaries named for various time periods in Moody's The Truth About the Trusts (1904). ${ }^{10}$ Patents pertaining to barrel-making, can-sealing, and petroleum applications inventions were excluded to maintain consistency with the Schmookler definitions. With the benefit of the doubt resolved in cases of imperfect name matches in favor of counting patents as Standard-originated, from 48 to 54 patents, or at most 12 percent of the comparable Schmookler count, had origins in Standard companies.

It is possible that some inventions made by standard employees were not assigned to the parent, and indeed, several cases were found in which employees assigned some patents to Standard units and retained individual rights to others. However, in 1871 U.S. law was revised to allow companies to require assignment of employee-made inventions, so Standard clearly had the right to mamdate assignment, and 16 Standard units were found to have received assignments during the sample period. ${ }^{11}$ Comprehensive data on patent assignments to corporations during the Standard monopoly period are sparse. The earliest data, derived from Historical Statistics of the United States (1960, p. 607), appear to be for 1901. From then

10 . The search utilized Index of Patents volumes located in the Patent Office's public search room, which were found to be in seriously deteriorated condition, and the better-maintained volumes (missing five years) in the Boston Public Library.

11 . See May and Sell (2006), p. 123. The count of Standard subsidiary assignees here includes several inventions on non-refining inventions, of which numerous cases were found. In 1778 William Rockefeller, John D. Rockefeller's brother and business associate, took personal assignment on a non-refining invention. 
to 1911, the number of U.S. patents assigned at the time of issue to U.S. corporations rose from 4,370 to 7,580 , i.e., from 17.1 to 23.1 percent of all patent issues. Thus, although much less prevalent that in recent times, assignments were both common and rising in the latter years of Standard's monopoly.

During the period in question, Standard had an expressly articulated policy of rejecting unpatented inventions brought to its attention by independent inventors, but screening the patents of outside inventors and acquiring rights to those it considered attractive. See Hidy and Hidy (1955), p. 288. Given this, one might argue that standard at least expressed a "demand pull" toward would-be petroleum process inventors, spurring their efforts, and perhaps acquiring many of the patents that my survey shows to have been assigned (i.e., at the time of issue) to independents. On this, very little information exists, although the Hidys report ( $p .288$ ) that no proposed outside improvement to the Frasch refining methods was considered worth pursuing. To the Frasch contribution we now turn.

\section{The Frasch Process}

Standard's lawyers' briefs and the consensus of historians suggest that inventions by Hermann Frasch were the most important technological contribution by Standard during the last three decades of the 19th Century. Allan Nevins (1953, vol. 2, p. 101) views the story of Frasch's invention as "one of the romances in the Standard annals." Unfortunately, the many historical accounts are often quite inconsistent. Nevins' complaint (1953, vol. 2, p. 443) that "A biography of Frasch yet remains much needed" continues even now to be valid. My analysis here attempts to make sense of the conflicting evidence. ${ }^{12}$

Demand-pull for the Frasch inventions emerged when John $D$. Rockefeller chose in the 1880s, contrary to his prior policy, to invest heavily in crude oil properties - - notably, in the vicinity of Lima, Ohio. But the oil that began flowing from Lima wells proved around 1886 or 1887 to have a sulphur content quite unsuitable for refining into Standard's principal profitearners - - illuminating oil, or kerosene, and lubricating oil. Lima-based kerosene burned with an offensive "skunk oil" smell

12 . It taps works listed in the References, several biographies of Frisch and William Burton found on the Worldwide Web, and an analysis of individual Frasch patents. 
and blackened the glass surrounding lamp flames, reducing their illuminating efficiency. Standard initially temporized by stockpiling Lima crude and then cultivating a demand for fuel oil, but that was a less profitable use of ohio oil than refining kerosene would be -- if the technology necessary for sulphur elimination were at hand. Standard's internal attempts to solve the problem were unsuccessful.

Hermann Frasch, born in Germany in late 1851, emigrated to the United States in 1868. ${ }^{13}$ He studied and obtained a laboratory assistant's job in the Philadelphia College of Pharmacy and is said to have been fascinated by chemistry in general and the emerging petroleum technology in particular. He saved enough money to establish his own chemical laboratory around 1873, pursuing inventions of his own choosing and also doing contract work for Philadelphia companies. This work led inter alia to inventions underlying U.S. patent no. 205,792, applied for in August 1877 and issued in 1878. Its focus was the "separation and treatment of oils," emphasizing what is now considered conventional fractional distillation. It claimed elimination of undesirable odors from volatile ingredients, but not with methods that resembled Frasch's later desulphurization inventions.

Frasch's petroleum invention came to the attention of Standard Oil, and Frasch was apparently enlisted as a chemist with a Standard subsidiary in Cleveland, to which he migrated around 1877.14 The nature of his duties in Cleveland has not been pinpointed in any of the definitive sources. He made and patented several inventions from his Cleveland base, one on the "fractional distillation of oil" and one on the manufacture of waxed paper - - the wax coming from petroleum-based paraffin. None of the inventions was assigned to standard 0il or any known affiliate of Standard; all but one went to Frasch personally without prior assignment. ${ }^{15}$ Reminiscing on his experiences upon receiving the Perkins Medal in chemistry for 1912, Frasch makes no mention of his early tenure as a Standard employee (Frasch 1912). His Cleveland work relationship apparently ended around

13 . His name was Anglicized to Herman during his U.S. residence.

14 . Frasch's first Cleveland-based patent was applied for in August 1877.

15 . The exception was assigned to J. B. Merriam of Cleveland. Whether Merriam had a connection to Standard Oil is unknown. 
1885. What might best be characterized as a biographical novel claiming to draw upon private communications with co-workers, Heiss (1942, pp. 36-40) suggests that John D. Rockefeller was outraged when he realized later that Frasch's superiors failed to recognize the chemist's genius and make every effort to retain him and put him to work on problems critical to standard Oil. ${ }^{16}$

What is well established is that around 1885 Frasch purchased oil production and refining properties in ontario and moved to London, Ontario. ${ }^{17}$ The purchase was made at bargain prices because the ontario oil proved to have a high sulphur content, leading to product failures and expensive law suits. Frasch went to work and solved the problem, proposing an array of metal oxides to absorb the sulphur and precipitate it from the refined oil. On his invention he obtained, in addition to Canadian patents, a basic U.S. patent no. 378,246, applied for February 21, 1887, and issued in February 1888. The invention quickly came to the attention of Standard 0il, which was urgently seeking solutions to its high-sulphur Lima problem. Standard purchased Frasch's company, Empire 0il, along with its desulphurization patent, apparently in an exchange of Standard oil stock for Empire stock, from which Frasch is said to have become quite wealthy. It also induced Frasch to return to Cleveland -- some accounts say at a considerable salary, some with compensation in Standard stock. Most sources put the date of this transfer as 1886, which is inconsistent with the fact that U.S. patent 378,246 lists Frasch's residence as London,

16 . An analogy to the history of AT\&T is suggested. Lee de Forest's triode electron tube (circa 1906) is widely considered one of the greatest inventions of all time, at least prior to conception of the transistor. In 1899 and 1900 de Forest was employed in the laboratories of Western Electric, AT\&T's manufacturing subsidiary. His spare time work on wireless (radio) technology enraged his supervisor, who, according to de Forest's diary, exclaimed, "Look here, de Forest. You'll never make a telephone engineer. As far as I am concerned you can go to hell, in your own way. Do as you damn please!" De Forest reports that he "took him at his word, turned to my little corner where I had my spark gap and responder parts, and thereafter spent eight hours a day at my own delectable tasks, totally oblivious to the telephone work going on about me and for which I was supposed to be paid." Maclaurin (1949) p. 72. De Forest left for another job a month later.

17 . Williamson and Daum (1959, vol. 1, p. 616), apparently err in stating that Frasch was hired by the Imperial Oil Company of Canada. They may have been confused (as I was initially) by the name of Frasch's Ontario company, Empire Oil, since there was also at the time a Standard Oil affiliate in Canada named Empire Refining Co. Ltd. 
Ontario, which must have been true at least at the February 1887 date of application. That the underlying inventions were made independently and not under standard employment is shown by the fact that Rockefeller paid a handsome price to acquire the Frasch properties and bring Frasch back into the Standard fold.

Frasch did begin intensive work on the sulphur problem. Early results were disappointing, but by october 1888, the Frasch process yielded merchantable kerosene. Work continued on alternative processing methods - - i.e., testing alternative metal oxides and means of recycling them, gaseous vs. liquid processing, and many equipment design variants - - improving yields and reducing costs. ${ }^{18}$ Expenditures of approximately $\$ 200,000$ on "the Herman experiment" were reported by Hidy and Hidy (1955, p. 165) - - a sum equivalent to more than \$2 million at year 2000 wholesale price levels. They yielded large returns to the Standard oil companies, increasing the value of Lima oil, and were extended from the Lima refinery to Standard's giant new refinery at Whiting, Indiana, built in the early 1890s. ${ }^{19}$

One of the many curiosities in the Frasch story is the choice of the name Frasch-Burton process in Standard 0il's defense against monopolization charges. William M. Burton, who received his Ph.D. in 1889, did work briefly as Frasch's assistant in Cleveland, but only beginning in 1890, after the Frasch process had been proven successful. Burton's main contribution appears to have been demonstrating to skeptical large-volume buyers that kerosene refined from ohio oil was as free of sulphur as kerosene from Pennsylvania oil. Or the designation could have been political, since Burton rose rapidly in the Standard organization and by 1895 was superintendent of its Whiting refinery.

18 . The first U.S. patent resulting from Frasch's new work in Ohio was number 448,480, applied for in October 1889 and issued in March 1891. It narrowed the set of oxides to copper and lead and reflected extensive experimentation.

19 . A remarkable fact difficult to reconcile with Alfred Chandler's emphasis on Standard Oil's success in securing economies of scale was that the Whiting, Indiana, refinery was designed to have 80 crude oil stills in order to achieve an unprecedented total capacity of 36,000 barrels per day. See Hidy and Hidy (1955, p. 164). A major source of petroleum refinery scale economies comes from the operation of the two-thirds rule in scaling up individual stills. Bestpractice modern refineries operate stills with a daily throughput of 200,000 barrels. Stills like those at Whiting in 1892 processing 450 barrels per day fell far short of this later condition. Compare Chandler (1990), pp. 21-25 and 93-96; with Scherer (1996), pp. 113-116. 
Frasch apparently continued to be employed by Standard 0il through much of the 1890s, assigning between 1891 and 1899 a total of 19 petroleum refining patents to Standard affiliates (mostly to Solar Refining, under which the Lima refinery operated) - - more than a third of all the patents traced to Standard oil in my search covering the years 1875 through 1899. His conditions of employment must have been sufficiently flexible that, in the early 1890s, he began working on a problem well outside the articulated interests of Standard - - mining sulphur from swampy deposits in Louisiana. From this research came a string of patents, the first three issuing in 1891, on what eventually came to be known as the Frasch process -- i.e., for extracting liquified sulphur from underground deposits through the injection of steam at high pressure. ${ }^{20}$ All were issued to himself and not assigned to standard oil. In his Perkins Medal address (1912, p. 138), Frasch reports that his early inventing and field experiments in Louisiana were "merely a hobby, the bulk of my time devoted to my Standard 0il work." In 1892, while still employed by Standard 0il, he organized the Union Sulphur Company, of which he became president. Union Sulphur soon became the leading supplier of sulphur in the United States, displacing imports from Sicily and Japan almost entirely.

\section{Evaluation}

The evidence on what Standard 0il attorneys considered the company's most noteworthy technological accomplishment -- the Frasch process - - yields a mixed verdict on Standard's leadership. The precipitating invention was made outside the Standard organization. Standard did show good insight in buying the basic Frasch patent, and it plowed what were for the time substantial sums into perfecting the process. My broader survey shows that relatively few patented inventions emerged from inventors who chose to assign, or whom standard required to assign, their inventions to the company. While the petroleum industry was expanding rapidly, the number of petroleum refining process patents stagnated, resuming a growth trajectory only after the divestiture of Standard into 34 segments following the Supreme Court's 1911 decision.

20 . The first patent resulting from Frasch's desulphurization work at Lima also issued in 1891. 
A more important negative indicator is the invention that was almost neglected. While the Standard 0il monopolization case was proceeding, the petroleum refining industry was subjected to two technological revolutions. The demand for kerosene illuminating oil -- Standard's principal early product - - was threatened by the advent of electric illumination, but the emergence of the automobile created demand for gasoline, which until then had been a nearly worthless by-product of the refining process. In 1907, 8.0 percent of American homes were wired for electricity; by 1912, the figure had doubled and continued rising to 34.7 percent in 1920 . In 1907, 43,000 passenger automobiles were produced; in 1912, 356,000; and after the first million-car year in 1916, factory sales reached 1.9 million in 1920. Using traditional methods, petroleum refiners were hard-pressed to extract enough gasoline to meet the burgeoning demand. A new process for obtaining a much higher fraction of gasoline from a barrel of crude oil - - thermal cracking - - was invented around 1909 by William Burton, Frasch's former assistant and in 1909 head of production at Standard 0il Company of Indiana. Indiana Standard applied to Standard headquarters in New York for authorization to spend \$1 million developing and installing thermal crackers. The request was turned down; the invention was considered too risky. ${ }^{21}$ Only when Standard of Indiana became independent in 1912 could the project go forward. The Burton process was widely licensed. Between 1913 and 1920, when competing cracking processes began to emerge, 91 million (42 gallon) barrels of gasoline had been refined using the Burton process. ${ }^{22}$

21 . See Yergen (1991), pp. 111-112; and Gibb and Knowlton (1956), pp. 116-117.

22 . Enos (1962), Appendix Table 1a. 


\section{REFERENCES}

de Chazeau, Melvin G., and Alfred Kahn (1959). Integration and Competition in the Petroleum Industry. New York: Yale University Press.

Chandler, Alfred D. (1990). Scale and Scope: The Dynamics of Industrial Capitalism. Cambridge: Harvard University Press.

Dictionary of American Biography (1931). New York: Scribner.

Enos, John L. (1962). Petroleum Progress and Profits: A History of Process Innovations. Cambridge: MIT Press.

Frasch, Herman (1912). "Address of Acceptance," Journal of Industrial and Engineering Chemistry, vol. 4, pp. 134-140.

Gibb, George S., and Evelyn Knowlton (1956). History of Standard Oil Company: The Resurgent Years 1911-1927. New York: Harper.

Hawthorne, Robert, biography of Herman Frasch in John Garraty and Mark Carnes, eds. (1999). American National Biography. New York: Oxford University Press.

Heiss, L. (1942). Der Schwefelkoenig von Louisiana (The Sulphur King of Louisiana). Reutlingen, Germany: Ensslin \& Laiblin.

Hidy, Ralph and Muriel (1955). Pioneering in Big Business. New York: Harper.

Maclaurin, William R. (1949). Invention and Innovation in the Radio Industry. New York: Macmillan.

May, Christopher, and Susan Sell (2006). Intellectual Property Rights: A Critical History. Lynne Rienner.

Moody, John (1904). The Truth About the Trusts. New York: Moody Publishing Co.

Nevins, Allan (1953). Study in Power: John D. Rockefeller, Industrialist and Philanthropist. Two volumes; New York: Scribner. 
Scherer, F. M. (1996). Industry Structure, Strategy, and Public Policy. New York: HarperCollins.

Scherer, F. M. (2008). "Technological Innovation and Monopolization," in W. D. Collins, ed., Issues in Competition Law and Policy (American Bar Association), vol. II, pp. 10331069 .

Schmookler, Jacob (undated). Statistics of Patents Classified by Industry, United States, 1837-1957. Privately published at the University of Minnesota.

Williamson, Harold F., and Arnold Daum (1959). The American Petroleum Industry: The Age of Illumination. Evanston: Northwestern University Press.

U.S. Bureau of Corporations (1907). Report of the Commissioner of Corporations on the Petroleum Industry. Washington.

U.S. Bureau of the Census, Historical Statistics of the United States: Colonial Times to 1957 (Washington: 1960).

U.S. Patent and Trademark Office (1875-1899). Index of Patents. Washington.

Yergin, Daniel (1991). The Prize. New York: Simon \& Schuster. 


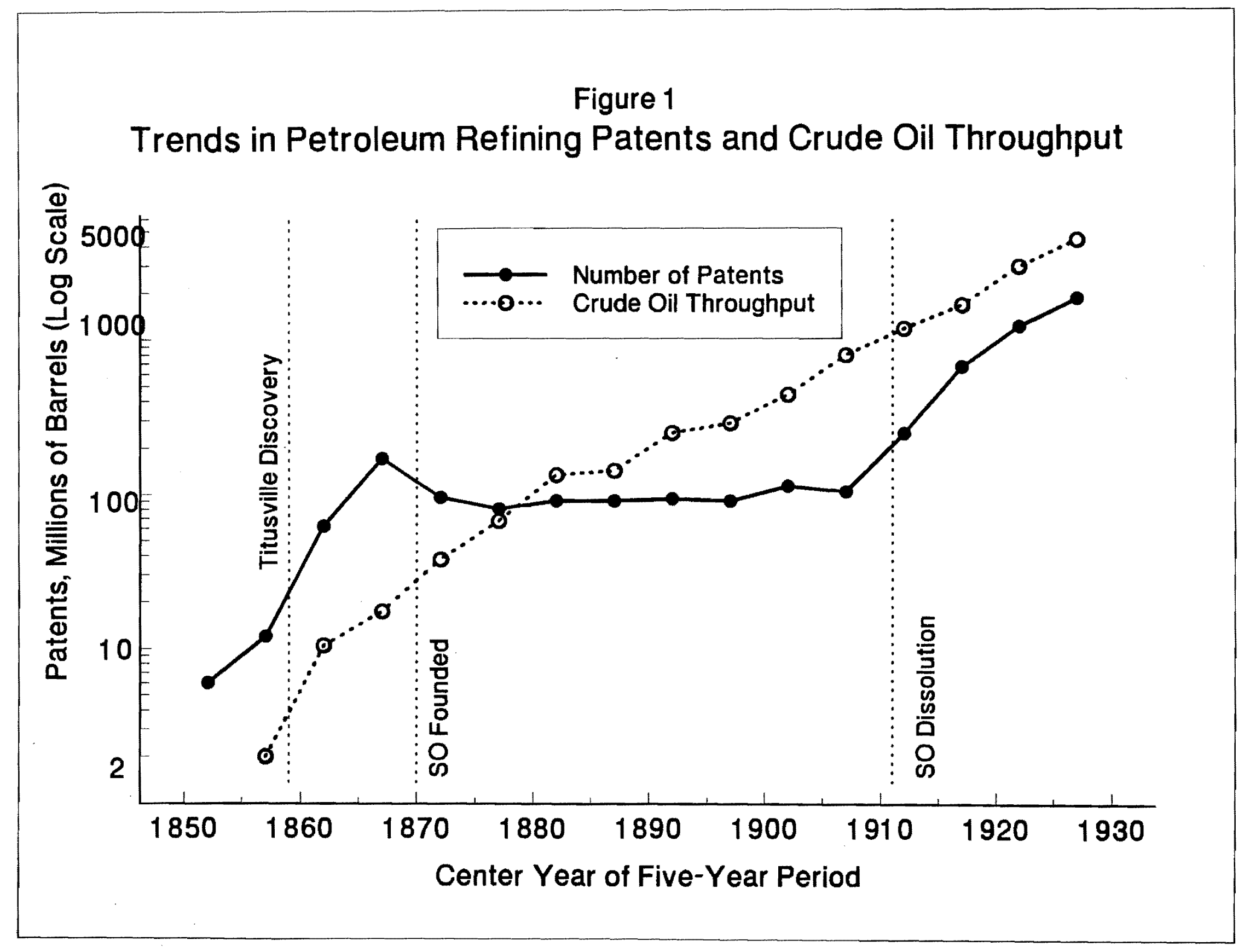

